\title{
State of the Art and Future Implications of SH003: Acting as a Therapeutic Anticancer Agent
}

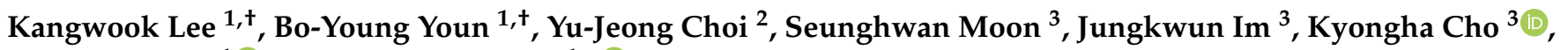 \\ Seong-Gyu Ko ${ }^{1}$ (D) and Chunhoo Cheon ${ }^{1, *(1)}$
}

Citation: Lee, K.; Youn, B.-Y.; Choi, Y.-J.; Moon, S.; Im, J.; Cho, K.; Ko, S.-G.; Cheon, C. State of the Art and Future Implications of SH003: Acting as a Therapeutic Anticancer Agent. Cancers 2022, 14, 1089. https:// doi.org/10.3390/cancers14041089

Academic Editor: Helmout Modjtahedi

Received: 29 January 2022

Accepted: 18 February 2022

Published: 21 February 2022

Publisher's Note: MDPI stays neutral with regard to jurisdictional claims in published maps and institutional affiliations.

Copyright: (C) 2022 by the authors. Licensee MDPI, Basel, Switzerland. This article is an open access article distributed under the terms and conditions of the Creative Commons Attribution (CC BY) license (https:// creativecommons.org/licenses/by/ $4.0 /)$.
1 Department of Preventive Medicine, Kyung Hee University, Seoul 02447, Korea; kwleeband@khu.ac.kr (K.L.); james_youn@khu.ac.kr (B.-Y.Y.); epiko@khu.ac.kr (S.-G.K.)

2 Department of Science in Korean Medicine, Graduate School, Kyung Hee University, Seoul 02447, Korea; ehowlqk11@naver.com

3 Department of Global Public Health and Korean Medicine Management, Graduate School, Kyung Hee University, Seoul 02447, Korea; mshssang@gmail.com (S.M.); ijk0109@hanmail.net (J.I.); marquis99@naver.com (K.C.)

* Correspondence: hreedom@khu.ac.kr; Tel.: +82-2-961-2382

+ These authors contributed equally to this work.

Simple Summary: This review discusses the prominent highlights of $\mathrm{SH} 003$, a herbal mixture that has the potential to become a notable anticancer agent in the future. Although developing an anticancer drug may take a lengthy approval process for any natural compounds or herbal mixtures to validate the positive effects from both non-clinical and clinical studies, the previous studies of SH003 have so far shown positive results in various malignancies, from both non-clinical and clinical studies.

\begin{abstract}
Cancer ranks as the first leading cause of death globally. Despite the various types of cancer treatments, negative aspects of the treatments, such as side effects and drug resistance, have been a continuous dilemma for patients. Thus, natural compounds and herbal medicines have earned profound interest as chemopreventive agents for reducing burden for patients. SH003, a novel herbal medicine containing Astragalus membranaceus, Angelica gigas, and Trichosanthes kirilowii, showed the potential to act as an anticancer agent in previous research studies. A narrative review was conducted to present the significant highlights of the total 15 SH003 studies from the past nine years. SH003 has shown positive results in both in vivo and vitro studies against various types of cancer cells; furthermore, the first clinical trial was performed to identify the maximum tolerated dose among solid cancer patients. So far, the potential of SH003 as a chemotherapeutic agent has been well-documented in research studies; continuous work on SH003's efficacy and safety is required to facilitate better cancer patient care but is part of the knowledge needed to understand whether SH003 has the potential to become a pharmaceutical.
\end{abstract}

Keywords: anticancer agent; cancer; natural compound; phytochemical; herbal medicine

\section{Introduction}

Cancer is the leading cause of death worldwide, according to the World Health Organization [1]. The top three types of cancer in 2020 were breast cancer (2.26 million cases), lung cancer (2.21 million cases) and colon and rectum cancer (1.93 million cases). Furthermore, the estimated number of deaths is expected to reach nearly 13.2 million by 2030 [2]. It is unfortunate that cancer still remains one of the highest causes of death regardless of the substantial progress in cancer diagnosis and treatments.

There are many types of cancer treatments, including chemotherapy, radiotherapy, surgery, hormone therapy, immunotherapy, etc. [3]. A single or combination therapy can be applied depending on the type of cancer; among the therapies, chemotherapy is one of the most common treatments to kill cancer cells and to stop them from growing rapidly [4]. 
Despite the favor of chemotherapies, such therapies have led to numerous side effects, drug resistance and inadequate target specificity [4]. Thus, there has been a significant interest in finding natural anticancer agents. Developing natural-product-based drugs may take longer than traditional cancer drugs; natural-product-based drugs are known to overcome the harmful effects of chemotherapies and possess the strengths to target various cancer types. On the negative side, the quality control of the undiscovered active components and sources of natural compounds may be challenging.

As natural compounds, such as carotenoids, flavonoids, anthocyanins, or terpenoids, have shown positive aspects as anticancer agents, the concept of chemoprevention has continuously developed and also become an excellent source of anticancer drugs [5,6]. It is noteworthy that more than $60 \%$ of approved anti-tumorigenic drugs are derived from natural sources [7].

The rise of natural compounds as anticancer agents and its relation to cancer treatment has been discussed among patients since conventional chemotherapy has posed a considerable burden for cancer patients. It is important to note that several studies have shown the use of natural substances to reduce the toxic burden on a patient's organs by a dose substitution with a natural compound, with a significantly positive effect [5]. Moreover, patients were able to tolerate high doses of natural compounds without any toxic effects [8].

Herbal medicines have also shown potential in reducing side effects while improving the immune system [9]. In particular, Chinese herbal medicine (CHM) has long been used to prevent and treat cancer in China. Huang et al. mentioned that arsenic trioxide, a toxic Chinese medicine, has been successfully applied in the clinical treatment of patients with acute promyelocytic leukemia; moreover, some formulae, including PHY906 based on Huang-Qin-Tang, have indicated a synergic effect with conventional drugs for improving the life quality of patients [10].

As previously stated, herbal medicines have been used with conventional chemotherapy or radiotherapy as a combination therapy to improve the efficacy of cancer treatment and reduce side effects, along with possible complications. Approximately between $28 \%$ and $98 \%$ of ethnic Chinese cancer patients in Asia have reported the utilization of integrative therapies with herbal medicines [11]; $25 \%$ to $47 \%$ of the patients living in North America also reported this.

With all that mentioned, natural compounds and herbal medicines, as well as herbal mixtures, have shown a considerable number of positive effects and have offered a superb opportunity for discovering therapeutic agents for the treatment of cancer.

Thus, the study aims to highlight the potentials of $\mathrm{SH} 003$, a herbal mixture, working as a vital anticancer agent, while providing evidence that it targets multiple metabolic pathways in both single-dose therapy and combined therapy along with conventional chemotherapeutics.

\section{Methods and Materials}

This study was written as a form of narrative review. All articles related to SH003 were searched for via PubMed with the keyword "SH003" in the textbox. There was a total number of 16 articles identified, and a protocol paper was excluded; therefore, the remaining 15 articles were carefully examined and summarized.

\section{Characteristics of $\mathrm{SHOO3}$}

SH003 is a mixture of Huang-Qi (Astragalus membranaceus; AG), Dang-Gui (Angelica gigas; AM), and Gua-Lou-Gen (Trichosanthes Kirilowii; TK), which are traditionally used in East Asian medicine. According to the theory of traditional medicine, the effect of HuangQi is to tonify qi, the effect of Dang-Gui is to tonify blood, and the effect of Gua-Lou-Gen is to disperse swelling and expel pus [12]. SH003 extracts were provided by HANPOONG (HANPOONG PHARM \& FOODS Co., Jeonju, Korea), which followed good manufacturing practice (GMP) procedures. In brief, Astragalus membranaceus (333 g), Angelica gigas (333 g), and Trichosanthes kirilowii Maximowicz (333 g) were mixed at a 1:1:1 ratio and 
then extracted with 10 times the volume of $30 \%$ ethanol at $100{ }^{\circ} \mathrm{C}$ for $3 \mathrm{~h}$. This process was performed 2 times. The extract was dried at reduced pressure (40 Torr) at $60{ }^{\circ} \mathrm{C}$ for $18 \mathrm{~h}$. Notably, the experimental study proved that Danggwibohyeoltang, a mixture of AM and AG, inhibits the immune-enhancing effect [13]. Meanwhile, we demonstrated that the ethanol extracts of TK induce apoptosis through inhibition of STAT3 activity in triplenegative breast cancer MDA-MB-231 cell lines [14]. Taken together, we finally decided to develop a novel anti-cancer herbal mixture by combining AG, AM and TK [15]. As shown in Figure 1, the anti-cancer effect of $\mathrm{SH} 003$ has been demonstrated by several publications.
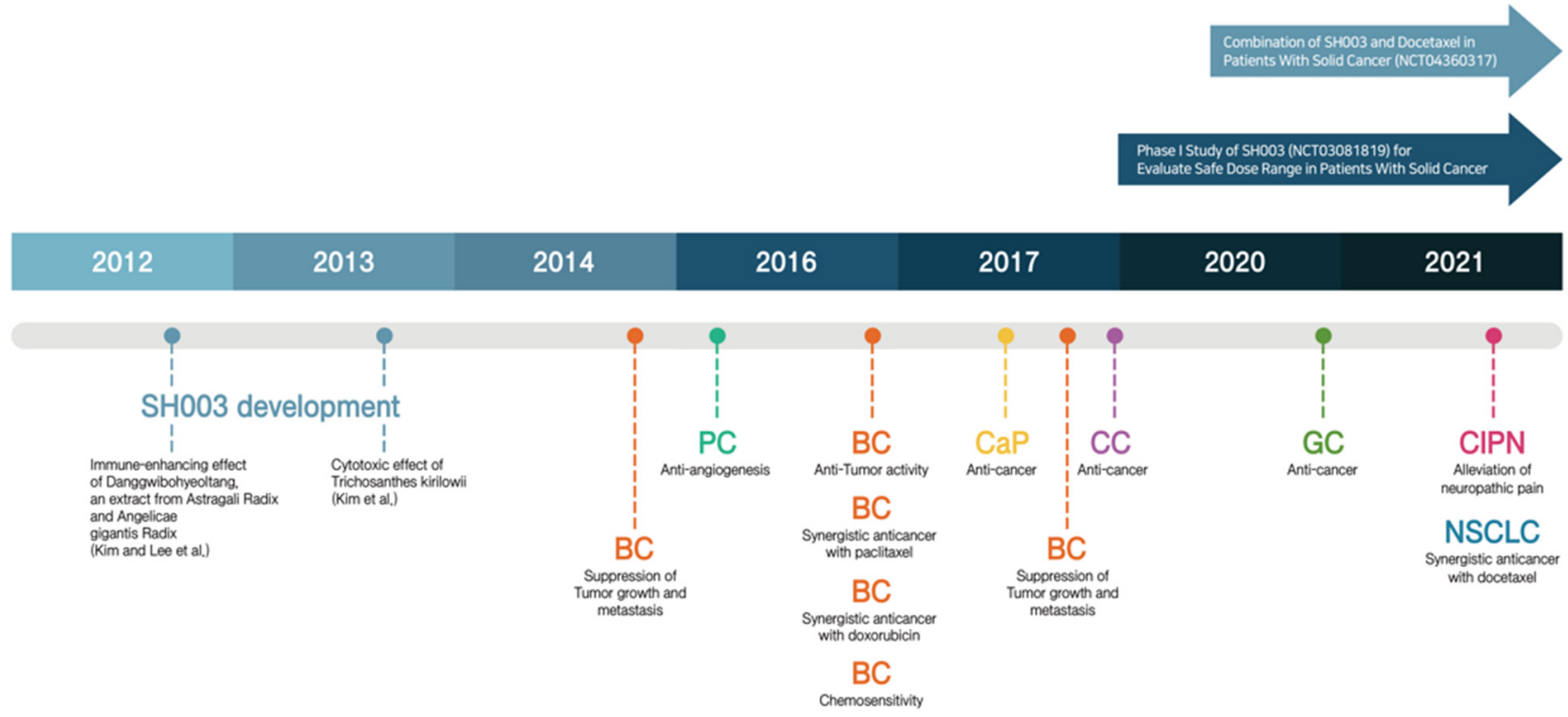

Figure 1. The timeline of SH003 (BC: breast cancer; PC: pancreatic cancer; CaP: prostate cancer; CC: cervical cancer; GC: gastric cancer, CIPN: chemotherapy-induced peripheral neuropathy and NSCLC: non-small cell lung cancer).

Toxicity studies with GLP regulations showed that SH003 is safe in rats [16]. In brief, rats were orally administrated SH003 (0, 500, 1000 and $2000 \mathrm{mg} / \mathrm{kg}$ ) every day for 2, 4 and 13 weeks. After administration, body weight, mortality, food intake, clinical signs, hematological values, serum biochemical values, relative organ weights and histopathology were recorded. The results show that the oral administration of SH003 does not result in any toxicological phenotypes. A dose-escalation study revealed that the no-observedadverse-effect level (NOAEL) is higher than $2500 \mathrm{mg} / \mathrm{kg}$ for both male and female rats. Furthermore, we further investigated the herb-drug interaction. Human liver microsomes were incubated with $\mathrm{SH} 003$, and then substrates including phenacetin, coumarin, paclitaxel, diclofenac, $( \pm)$-mephenytoin, dextromethorphan and midazolam were added. As a result, SH003 exhibited a minimal inhibitory effect on all CYP isozymes, suggesting that there was no herb-drug interaction. Based on the findings, we concluded that SH003 might be safe for cancer patients, and further clinical studies should be carried out to confirm the exact benefit of $\mathrm{SH} 003$ in cancer therapy.

In recent years, clinical trials to confirm safety have also been conducted. A phase I study evaluating the maximum tolerated dose for SH003 administration alone confirmed the daily safe dose to be up to $4800 \mathrm{mg}$ [17]. A clinical trial to ensure the maximum tolerated dose when administered in combination with docetaxel is also being conducted [18].

\section{Current Advances of SH003 in Tumor Suppression}

Herbal medicines have been used to prevent or inhibit tumor growth and metastasis. SH003 plays a crucial role in regulating various types of cancer (Figure 2 and Table 1). In this regard, the anti-cancer effect and mechanisms of SH003 against a wide range of cancers based on in vitro and in vivo studies are discussed here. 


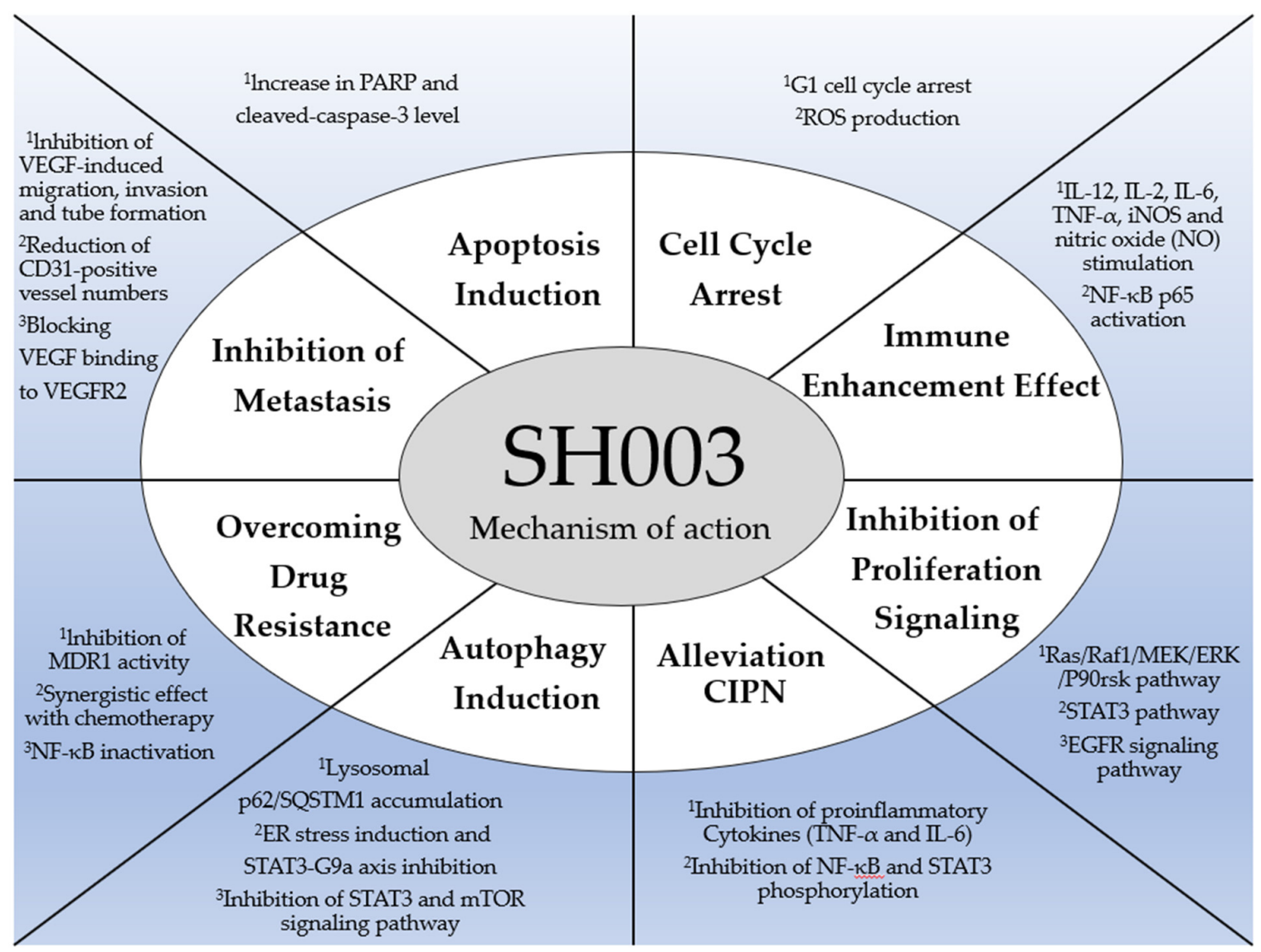

Figure 2. A mechanistic review of $\mathrm{SH} 003$.

\subsection{Breast Cancer}

Breast cancer is a leading cause of cancer death in women [19]. Based on the immunohistochemistry biomarkers, including estrogen receptor (ER), progesterone receptor (PR), and HER2, breast cancer is classified into the following subgroups; luminal A (ER+, PR \pm , HER2 - ), luminal B (ER+, PR \pm , HER2+), HER2 (ER-, PR - , HER2 overexpression) and basal-like triple-negative $(\mathrm{ER}-, \mathrm{PR}-, \mathrm{HER} 2-)$ breast cancer $[20,21]$. While conventional targeted therapies on ER, PR, or HER2 have been applied for breast cancer patients with luminal A, luminal B, or HER2 subtypes, the treatment options for triple-negative breast cancer (TNBC) are still limited, resulting in poor prognosis [22,23]. Therefore, the discovery of new anti-cancer agents for the treatment of TNBC patients is still needed.

In 2014, our group reported the tumor-suppressive effect of SH003 on triple-negative breast cancer [15]. It was shown that SH003 inhibits tumor growth and metastasis to the lung in the mouse xenograft model via the down-regulation of vascular endothelial cell marker (CD31). From in vitro results, SH003 inhibited the growth of various breast cancer cell lines, including luminal A, luminal B, HER2, and TNBC subgroups, when compared with the normal epithelial cell. Moreover, treatment with SH003 inhibited migration, invasion, and the anchorage-dependent colony formation of MDA-MB-231 TNBC cell lines. Western blot analysis revealed that SH003 decreased the expression of STAT3 phosphorylation and STAT3-dependent proteins. Meanwhile, SH003 also blocked the nuclear translocation of phosphorylation and the transcriptional activities of STAT3 in MDA-MB-231 cells. By inhibiting STAT3 activation, SH003 decreased the production of STAT3-mediated IL-6. Evidence showed for the first time that SH003 could be a novel anti-cancer herbal mixture for TNBC by inhibiting the STAT3-IL-6 autocrine loop. Another study was performed to define the growth-inhibitory effect of SH003 on p53-mutant TNBC [24]. SH003 has a significant anti-cancer effect via p73-mediated apoptosis in TNBC cells with p53 mutation. In 2017, Choi et al. found that SH003 suppresses the growth of 
TNBC cell lines by inducing autophagy and apoptosis [16]. SH003 induces autophagy by inhibiting STAT3 and mTOR signaling pathways, inducing lysosomal p62/SQSTM1 accumulation-mediated reactive oxygen species (ROS) generation. SH003-induced p62 accumulation in autophagosome caused ROS-mediated apoptotic death in TNBC cell lines. In a mouse xenograft model, SH003 dose-dependently inhibited tumor growth with the down-regulation of Ki-67 and phosphorylation of STAT3, and up-regulation of p62. Accumulating data from several studies about $\mathrm{SH} 003$ demonstrate that $\mathrm{SH} 003$ is a novel herbal mixture for TNBC treatment by causing apoptotic cell death and autophagy.

Conventional chemotherapy has faced limitations such as multi-drug resistance $[25,26]$. To overcome the resistance, it is necessary to develop an alternative therapeutic strategy, such as combination chemotherapy, which sensitizes cancer cells to each drug, and decreases side effects by reducing the dose $[27,28]$. In recent years, several anti-cancer agents, including taxane and doxorubicin, have been trialled in combinational therapy against breast cancer. Moreover, a combination of herbal medicines and conventional chemotherapies has been suggested $[28,29]$. Considering a combinational strategy for TNBC treatment, we further investigated whether SH003 and doxorubicin exhibit a synergistic effect on TNBC treatment [30]. SH003 and doxorubicin synergistically inhibited the cell viability of TNBC MDA-MB-231 cell lines. Moreover, this synergistic cell death was associated with caspase-dependent apoptosis in MDA-MB-231 cell lines. The tumor growth of MDAMB-231 in mouse xenograft models was synergistically decreased by the combinational treatment of $\mathrm{SH} 003$ with doxorubicin. Thus, this study suggests that a combination treatment of SH003 and doxorubicin would be a novel strategy for TNBC treatment. In addition, further studies examined whether SH003 treatment can overcome paclitaxel resistance in ER+ breast cancer [31]. Choi et al. investigated the inhibitory effect of SH003 on MDR1 activity in paclitaxel-resistant ER+ breast cancer MCF7 cell lines (MCF7/PAX). The results show that $\mathrm{SH003}$ and paclitaxel inhibited the viability of MCF7/PAX in a synergistic manner. Of note, the SH003 inhibition of MDR1 expression sensitized MCF7/PAX to paclitaxel. Seo et al. further examined the molecular mechanism of SH003 in overcoming paclitaxel resistance in MCF7/PAX. SH003 decreased the viability of MCF7/PAX by inducing cell cycle arrest and apoptosis [32]. Moreover, SH003 treatment down-regulated the expression of phosphor-STAT3 and prevented the translocation of STAT3 into the nucleus. Taken together, the above studies demonstrated that $\mathrm{SH} 003$ could overcome drug resistance by targeting MDR1 and STAT3 and suggested that SH003 is likely to be a partner with conventional chemotherapy for overcoming drug resistance.

\subsection{Lung Cancer}

According to the American Cancer Society, lung cancer has been by far the top-ranked cancer for death among both men and women, from 1998 to 2021 [19,33]. According to microscopic features, lung cancer is classified into non-small cell lung cancer (NSCLC) and small-cell lung cancer (SCLC) [34,35]. NSCLC patients commonly receive platinum or taxanebased regimens or targeted therapy for epidermal growth factor receptor (EGFR) [36,37]. Docetaxel-taxane with anti-mitotic properties-is an effective anti-cancer agent, causing cell cycle arrest and apoptosis in NSCLC [38-40]. However, docetaxel-mediated chemoresistance and severe side effects, including peripheral neuropathy, anorexia, and cachexia, are still the cause of treatment failure in cancer patients [41,42]. Recent studies have focused on the development of novel treatment strategies by combining chemotherapy with herbal medicines for NSCLC treatment [29,43]. Several clinical studies demonstrated the survival benefit of chemotherapy in combination with traditional Chinese herbal medicines in cancer patients [44-46]. Thus, we hypothesized that the combination treatment of SH003 and docetaxel is effective for NSCLC patients [47]. The results of an MTT cell viability assay showed that the co-treatment of $\mathrm{SH} 003$ and docetaxel synergistically inhibited the viability of NSCLC A549 and H460 cell lines. Furthermore, FACS and Western blot analysis demonstrated that combination treatment with the lowest combination index effectively induced apoptotic cell death when compared with a single treatment with $\mathrm{SH} 003$ or do- 
cetaxel. Moreover, since EGFR has a pivotal role in cancer progression, metastasis, and drug resistance in NSCLC, the combinational effect of SH003 and docetaxel on the EGFR signaling pathway was also examined. The results show that this combination treatment synergistically inhibited the expression of phosphor-EGFR (Y1068) in H460 cell lines with or without epidermal growth factor (EGF). Additionally, downstream of the EGFR, the JAK/STAT3 signaling pathway was decreased under combination treatment. An in vivo study confirmed that the combination of SH003 and docetaxel more strongly inhibited the tumor growth than single treatment with each agent. Immunohistochemical staining showed that combination treatment effectively increased the apoptosis marker (cleaved caspase 3) and decreased survival marker (Ki-67), phospho-EGFR(Y1068), and phosphoSTAT3 (Y705). Thus, this study concluded that docetaxel treated with SH003 synergistically induced apoptotic cell death by inhibiting the EGFR-STAT3 signaling pathway in EGFR wild-type NSCLC.

\subsection{Other Malignancies}

Besides breast and lung cancer, the anti-cancer effects of SH003 on other cancer types have been investigated by non-clinical studies [48-50]. In 2016, Choi et al. investigated the anti-cancer effects of SH003 in prostate cancer cells [48]. SH003 treatment dose-dependently inhibited the viability of prostate cancer DU145 cell lines by inducing apoptosis. Moreover, SH003 induced apoptotic cell death via inhibiting the ERK signaling pathway, while ERK overexpression reversed it. In the case of cervical cancer, Lee et al. demonstrated that SH003 exhibits an anti-cancer effect by regulating cell cycle arrest and apoptotic cell death [49]. Kim et al. reported the effect of SH003 on the autophagic death of gastric cancer cells [50]. In gastric cancer, $\mathrm{SH} 003$ treatment dose- and time-dependently inhibited the viability of various gastric cancer cell lines, the inhibition of which was associated with the induction of apoptosis. Meanwhile, SH003 also induced ER stress via PERK-ATF4-CHOP signaling, inhibiting G9a by suppressing STAT3 phosphorylation and activating autophagy. Of note, SH003-induced ER stress induced BNIP3-related autophagic death via the suppression of STAT3/G9a axis under hypoxic conditions.

\subsection{Tumor Angiogenesis}

Tumor angiogenesis is crucial for tumor growth and distant metastasis [51,52]. The inhibition of tumor angiogenesis has been considered a potential target for cancer treatment. Vascular endothelial cell growth factor (VEGF) released from cancer cells binds to VEGF receptor (VEGFR) on vascular endothelial cells, resulting in neo-angiogenesis. Based on the finding that SH003 suppressed TNBC tumor growth with the down-regulation of endothelial cell marker (CD31) in a mouse xenograft model [15], Choi et al. performed a further study to prove an anti-angiogenic effect of SH003 [53]. While VEGF induced the migration, invasion, and tube formation of human vascular endothelial cells (HUVEC), SH003 treatment inhibited it. Moreover, SH003 dose- and time-dependently inhibited the VEGF-mediated activation of VEGFR2 downstream in HUVEC. In the mouse xenograft model, a low dose of SH003 (2 mg/ kg) decreased tumor growth. Immunohistochemistry results show that SH003 reduced the expression of Ki-67, phospho-VEGFR2 and vascular endothelial cell marker (CD31), and increased apoptosis marker (cleaved caspase 3) in tumor tissues, suggesting that SH003 administration decreased the tumor growth by inhibiting tumor angiogenesis. Further vascular leakage assays confirmed the anti-angiogenic effect of SH003. Thus, these data encourage SH003 development for a novel anti-angiogenic agent, as well as a cytotoxic agent.

\subsection{Managing Cancer-Related Adverse Effect}

4.5.1. Chemotherapy-Induced Peripheral Neuropathy

As mentioned above, chemotherapy causes severe side effects. Chemotherapy-induced peripheral neuropathy (CIPN) is one of the painful side effects characterized by damage to peripheral neurons [54]. Cancer patients who receive docetaxel experience acute pain 
syndrome [55,56]. Regardless of the therapeutic benefit of docetaxel, patients may consider the cessation of cancer treatment because of painful symptoms. Unfortunately, there have been no effective options for the treatment of CIPN. Researchers reported that herbal medicines could be novel therapeutic options for relieving cancer-related side effects, including CIPN $[29,57]$. In 2021, the therapeutic effect of the novel herbal mixture SH003 on docetaxel-induced neuropathic pain was reported [58]. Lee et al. demonstrated that SH003 alleviated mechanical allodynia in the docetaxel-induced mouse CIPN model. Intravenous docetaxel injection induced the degeneration of intraepidermal nerve fibers in the feet of C57BL/ 6 mice, but SH003 treatment alleviated it. Additionally, SH003 decreased the upregulation of TNF- $\alpha$ and IL- 6 in plasma and increased expression of phospho-NF- $k B$ and phospho-STAT in L4-L6 spinal cord and sciatic nerves in docetaxel-injected mice. Based on these findings, therapeutic indications of SH003 can be expanded to CIPN in addition to killing cancer.

\subsubsection{Immune-Enhancing Effect}

The immune system of cancer patients who receive several therapies, including chemotherapy and radiotherapy, is commonly weakened, resulting in tumor progression and poor prognosis $[59,60]$. Several studies reported that herbal medicines and their derivatives exhibit immunostimulatory effects [61,62]. Han et al. demonstrated that SH003 improves immunosuppression via the activation of immune cells such as macrophages, splenocytes, and NK cells [63]. SH003 treatment increased the production of colony-stimulating factors, IL-2, IL-6, IL-12, TNF- $\alpha$, nitric oxide, and iNOS. Moreover, the transcription factor NF- $\kappa \mathrm{B}$ was enhanced by SH003. In splenocytes, $\mathrm{SH} 003$ also stimulated the production of IFN- $\gamma$, IL-2, IL-12, TNF- $\alpha$, and nitric oxide. The splenic lymphocyte proliferation and splenic NK cell activity were increased by SH003 treatment. In the cyclophosphamide-induced immunosuppression murine model, SH003 alleviated immunosuppression with the increased production of IFN- $\gamma$, IL-2, IL-6, IL-12, and TNF- $\alpha$ in serum and spleen. These data suggest that $\mathrm{SH} 003$ could be applied as an immunostimulatory agent for immunosuppressive disease.

Table 1. A summary of the effects of $\mathrm{SH} 003$ on cancer, immune system and chemotherapy-related side effects.

\begin{tabular}{|c|c|c|c|c|c|}
\hline Cancer Type & Cell Type & Proposed Effects & Methods & Mechanism & Refs. \\
\hline \multirow{5}{*}{ Breast cancer } & MDA-MB-231 & $\begin{array}{l}\text { Suppression of tumor } \\
\text { growth and metastasis }\end{array}$ & $\begin{array}{c}\text { in vitro } \\
(0-500 \mu \mathrm{g} / \mathrm{mL}) \\
\text { in vivo } \\
(500 \mathrm{mg} / \mathrm{kg})\end{array}$ & $\begin{array}{l}\text { Inhibition STAT3-IL-6 } \\
\text { Signaling }\end{array}$ & [15] \\
\hline & $\begin{array}{l}\text { MDA-MB-231 and } \\
\text { HCC-38 }\end{array}$ & $\begin{array}{l}\text { Pro-apoptosis and } \\
\text { autophagy induction }\end{array}$ & $\begin{array}{c}\text { in vitro } \\
(0-500 \mu \mathrm{g} / \mathrm{mL}) \\
\text { in vivo } \\
(10,100,500 \mathrm{mg} / \mathrm{kg})\end{array}$ & $\begin{array}{l}\text { Accumulation p62 in } \\
\text { autolysosomes }\end{array}$ & [16] \\
\hline & $\begin{array}{c}\text { Hs578T, } \\
\text { MDA-MB-231, } \\
\text { ZR-75-1, MCF7 } \\
\text { and T47D }\end{array}$ & $\begin{array}{l}\text { Pro-apoptosis, } \\
\text { synergistic anticancer } \\
\text { effect with paclitaxel }\end{array}$ & $\begin{array}{c}\text { in vitro } \\
(0-200 \mu \mathrm{g} / \mathrm{mL})\end{array}$ & $\begin{array}{l}\text { Increase in p73 } \\
\text { expression }\end{array}$ & {$[24]$} \\
\hline & MDA-MB-231 & $\begin{array}{c}\text { Pro-apoptosis, } \\
\text { synergistic anticancer } \\
\text { effect with } \\
\text { doxorubicin }\end{array}$ & $\begin{array}{c}\text { in vitro } \\
(0-500 \mu \mathrm{g} / \mathrm{mL}) \\
\text { in vivo } \\
(500 \mathrm{mg} / \mathrm{kg})\end{array}$ & $\begin{array}{c}\text { Caspase cascade } \\
\text { activation }\end{array}$ & [30] \\
\hline & $\begin{array}{l}\text { Paclitaxel-resistant } \\
\text { breast cancer cell } \\
\text { (MCF-7/PAX) }\end{array}$ & $\begin{array}{l}\text { Overcoming drug } \\
\text { resistance }\end{array}$ & $\begin{array}{c}\text { in vitro } \\
(0-500 \mu \mathrm{g} / \mathrm{mL})\end{array}$ & $\begin{array}{l}\text { Inhibition of MDR1 } \\
\text { activity, inhibition of } \\
\text { STAT3 signaling } \\
\text { pathway }\end{array}$ & {$[31,32]$} \\
\hline
\end{tabular}


Table 1. Cont.

\begin{tabular}{|c|c|c|c|c|c|}
\hline Cancer Type & Cell Type & Proposed Effects & Methods & Mechanism & Refs. \\
\hline $\begin{array}{l}\text { Endothelial } \\
\text { cells }\end{array}$ & $\begin{array}{l}\text { Human umbilical } \\
\text { vein endothelial } \\
\text { cells (HUVECs) }\end{array}$ & Anti-angiogenesis & $\begin{array}{c}\text { in vitro } \\
(0-50 \mu \mathrm{g} / \mathrm{mL}) \\
\text { in vivo } \\
(2 \mathrm{mg} / \mathrm{kg})\end{array}$ & $\begin{array}{c}\text { Blockade VEGF } \\
\text { binding to VEGFR2 }\end{array}$ & [53] \\
\hline Prostate cancer & DU145 & Pro-apoptosis & $\begin{array}{c}\text { in vitro } \\
(0-500 \mu \mathrm{g} / \mathrm{mL})\end{array}$ & $\begin{array}{c}\text { Inhibition ERK } \\
\text { signaling pathway }\end{array}$ & [48] \\
\hline Cervical cancer & $\mathrm{HeLa}$ & Pro-apoptosis & $\begin{array}{c}\text { in vitro } \\
(0-500 \mu \mathrm{g} / \mathrm{mL})\end{array}$ & $\begin{array}{l}\text { G1 cell cycle arrest, } \\
\text { ROS generation }\end{array}$ & [49] \\
\hline Gastric cancer & AGS and SNU-638 & Autophagic cell death & $\begin{array}{c}\text { in vitro } \\
(0-400 \mu \mathrm{g} / \mathrm{mL})\end{array}$ & $\begin{array}{l}\text { ER stress induction } \\
\text { and inhibition of } \\
\text { STAT3-G9a axis }\end{array}$ & {$[50]$} \\
\hline $\begin{array}{l}\text { Non-Small Cell } \\
\text { Lung Cancer }\end{array}$ & $\mathrm{H} 460$ & $\begin{array}{l}\text { Synergistic anticancer } \\
\text { effect with docetaxel }\end{array}$ & $\begin{array}{c}\text { in vitro } \\
(0-500 \mu \mathrm{g} / \mathrm{mL}) \\
\text { in vivo } \\
(557.569 \mathrm{mg} / \mathrm{kg})\end{array}$ & $\begin{array}{c}\text { Inhibition } \\
\text { EGFR-STAT3 } \\
\text { signaling pathway }\end{array}$ & [47] \\
\hline C57BL/6 Mice & $\begin{array}{l}\text { Docetaxel-Induced } \\
\text { Neuropathy } \\
\text { Mouse Model }\end{array}$ & $\begin{array}{c}\text { Alleviation of } \\
\text { docetaxel-induced } \\
\text { neuropathic pain }\end{array}$ & $\begin{array}{c}\text { in vivo } \\
(557.569 \mathrm{mg} / \mathrm{kg})\end{array}$ & $\begin{array}{c}\text { Inhibition of } \\
\text { proinflammatory } \\
\text { cytokines (TNF- } \alpha \text { and } \\
\text { IL-6), NF-kB and } \\
\text { STAT3 }\end{array}$ & [58] \\
\hline Immune cell & $\begin{array}{l}\text { Macrophage (RAW } \\
\text { 264.7) and NK cell }\end{array}$ & $\begin{array}{l}\text { Immune-enhancing } \\
\text { activity }\end{array}$ & $\begin{array}{c}\text { in vitro } \\
(0-500 \mu \mathrm{g} / \mathrm{mL}) \\
\text { in vivo } \\
(400 \mathrm{mg} / \mathrm{kg})\end{array}$ & $\begin{array}{c}\text { Production } \\
\text { immunostimulatory } \\
\text { cytokines and NO, } \\
\text { activation of NF-kB }\end{array}$ & [63] \\
\hline
\end{tabular}

\subsection{Anti-Cancer Effect of SHOO3 Derivatives}

Since $\mathrm{SH} 003$ is a herbal mixture that contains multiple phytochemicals, it was necessary to decipher what compounds of SH003 show anti-cancer effects. From 2012 to 2020, the SH003 research group has found apigenin, cucurbitacin D, decursin, kaempferol, and quercetin as potential anti-cancer agents (Table 2). In brief, a number of studies have demonstrated that each putative active compound mainly regulates the signaling pathways in apoptosis or autophagy, which are the key anticancer targets of SH003. Therefore, SH003 is expected to have anticancer effects through the synergistic effect of these compounds, although non-clinical studies should prove this. Moreover, the previous research focused on the chemical profiling of SH003 identified several constituents, whereas the anticancer effect of single components and their combination are still unknown [16]. However, there are still undiscovered active components in $\mathrm{SH} 003$. Thus, further studies should be performed to identify new compounds in $\mathrm{SH} 003$ and to investigate the synergistic interactions of multiple components.

\subsubsection{Apigenin}

One of the phytoestrogens, apigenin induced the cell p53-dependent apoptotic death of HER2-overexpressing breast cancer MCF7 cells engineered to overexpress oncogenic HER2 (MCF7-HER2) [64]. Moreover, apigenin-induced cell death resulted from the inhibition of STAT3 and the NF- $\mathrm{kB}$ signaling pathway. Another study demonstrated that apigenin inhibits hypoxia-induced VEGF production from HER2-overexpressing breast cancer MDAMB-453 cells [65]. Furthermore, apigenin decreased MDR1 expression in doxorubicinresistant MCF7 cells by blocking the STAT3 signaling pathway, which could contribute to overcoming multi-drug resistance [66]. 


\subsubsection{Cucurbitacin D}

Cucurbitacin D has been known to display anti-cancer and anti-inflammatory activity $[67,68]$. In 2015, Ku et al. demonstrated that cucurbitacin D kills doxorubicin-resistant MCF7 cells by inducing cell cycle arrest and apoptosis [69]. Moreover, cucurbitacin Dinduced cell death was associated with inhibiting STAT3 and the NF- $\mathrm{kB}$ signaling pathway. It was also reported that Tk or cucurbitacin D combined with cisplatin/pemetrexed synergistically induces the apoptotic death of non-small-cell lung cancer H1299 cells by suppressing ErbB3 signaling pathways [70]. In 2020, Hong et al. proved that cucurbitacin D blocks EGF binding to EGFR, followed by the inhibition of growth and migration of gefitinib-resistant NSCLC cells. This study concluded that cucurbitacin D could be a novel agent for overcoming gefitinib resistance via targeting the EGF-EGFR signaling pathway in gefitinib-resistant NSCLC. In recent years, the anti-cancer effect of cucurbitacin D against pancreatic cancer was reported [71]. Cucurbitacin D dose-dependently inhibited the viability of pancreatic cancer cell lines by inducing G2/M cell cycle arrest and apoptosis. Moreover, cucurbitacin D-mediated ROS production regulates cell cycle arrest and apoptosis in pancreatic cancer cell lines. It is worth noting that cucurbitacin D-induced ROS generation sequentially activates the p38/c-jun signaling pathway and, in turn, triggers apoptotic cell death.

\subsubsection{Decursin}

Decursin has been known as a major component of AG, which exhibits a potential anti-cancer effect on several malignancies [72]. In 2016, Choi et al. reported that the main active component of AG, decursin, sensitizes doxorubicin-resistant ovarian cancer cells to doxorubicin [73]. Co-treatment of decursin and doxorubicin synergistically induces cell death and apoptotic cell death. Moreover, it is worth noting that overcoming doxorubicin resistance by decursin treatment is mediated by the inhibition of P-glycoprotein expression.

\subsubsection{Kaempferol}

Kaempferol is a naturally occurring flavonoid and possesses anti-cancer activity against several malignancies [72]. In 2018, Kim et al. reported kaempferol's anti-cancer effect and molecular mechanism on gastric cancer [73]. Kaemferol induced autophagic cell death by inhibiting p62 and activating IRE1-JNK-CHOP signaling. Moreover, kaempferol epigenetically modified G9a (HDAC/G9a) followed by autophagic cell death.

\subsubsection{Quercetin}

Quercetin has been shown to exhibit antioxidant, anti-inflammatory, and anti-angiogenic properties [74-76]. Notably, the anti-cancer effect of quercetin has been well-documented in accumulating numbers of publications, both in cell and animal models [77,78]. In 2016, our group reported the anti-proliferative effects of quercetin on HER2-overexpressed breast cancer BT-474 cells [79]. The results show that quercetin dose- and time-dependently suppresses the growth of BT- 474 cells. According to the anchorage-dependent and -independent assay, quercetin effectively inhibited the colony formation of BT-474 cells. Moreover, quercetin treatment triggered G1-phase arrest of cell cycle progression and caspase-dependent extrinsic apoptosis, but not intrinsic apoptosis. Quercetin-induced apoptotic cell death was accompanied by a decrease in STAT3 expression and transcriptional activity. 
Table 2. A summary of SH003 derivative-induced effects on cancer treatment.

\begin{tabular}{|c|c|c|c|c|}
\hline Herb & Active Compound & Cancer Type/Cell Type & Mechanism & Refs. \\
\hline $\begin{array}{c}\text { Astragalus membranaceus, } \\
\text { Trichosanthes Kirilowii } \\
\text { Maxim. }\end{array}$ & $\begin{array}{c}\text { Apigenin } \\
(0-40 \mu \mathrm{M}[64]) \\
(0-100 \mu \mathrm{M}[65,66])\end{array}$ & $\begin{array}{c}\text { Breast cancer (MCF-7. } \\
\text { SK-BR-3, BT-474, } \\
\text { MDA-MB-453, MCF-7 } \\
\text { HER-2 and MCF7/ADR) }\end{array}$ & $\begin{array}{l}\text { Inhibition of STAT3 and } \\
\text { NFKB signaling, } \\
\text { downregulation of MDR1 } \\
\text { expression }\end{array}$ & [64-66] \\
\hline $\begin{array}{c}\text { Astragalus membranaceus, } \\
\text { Trichosanthes Kirilowii } \\
\text { Maxim. }\end{array}$ & $\begin{array}{l}\text { Quercetin } \\
(0-100 \mu \mathrm{M})\end{array}$ & Breast cancer (BT-474) & $\begin{array}{c}\text { Apoptosis through inhibition } \\
\text { of STAT3 }\end{array}$ & [79] \\
\hline Astragalus membranaceus & $\begin{array}{l}\text { Kaempferol } \\
(0-100 \mu \mathrm{M})\end{array}$ & $\begin{array}{c}\text { Gastric cancer (AGS, } \\
\text { SNU-216, NCI-N87, } \\
\text { SNU-638, and MKN-74) }\end{array}$ & $\begin{array}{l}\text { Activaiton of } \\
\text { IRE1-JNK-CHOP pathway, } \\
\text { G9a inhibition }\end{array}$ & [73] \\
\hline \multirow{3}{*}{$\begin{array}{l}\text { Trichosanthes Kirilowii } \\
\text { Maxim. }\end{array}$} & \multirow{3}{*}{$\begin{array}{l}\text { Cucurbitacin D } \\
(0-2 \mu \mathrm{g} / \mathrm{mL}[69]) \\
(0-10 \mu \mathrm{M}[70]) \\
(0-0.8 \mu \mathrm{M}[71])\end{array}$} & $\begin{array}{c}\text { Doxorubicin-resistant } \\
\text { human breast carcinoma } \\
\text { (MCF7/ADR) }\end{array}$ & $\begin{array}{l}\text { Inhibition of STAT3 and } \\
\text { NFKB signaling }\end{array}$ & [69] \\
\hline & & $\begin{array}{c}\text { Non-small-cell lung cancer } \\
\text { (H1299, HCC827 and } \\
\text { HCC827GR) }\end{array}$ & $\begin{array}{c}\text { ErbB3 and EGFR signaling } \\
\text { inhibition, synergistic effect } \\
\text { with CDDP/PXD, } \\
\text { overcoming gefitinib } \\
\text { resistance }\end{array}$ & {$[70]$} \\
\hline & & $\begin{array}{l}\text { Pancreatic cancer } \\
\text { (Capan-1) }\end{array}$ & $\begin{array}{l}\text { G2/M phase arrest through } \\
\text { ROS-p38 pathway }\end{array}$ & [71] \\
\hline Angelica gigas Nakai & $\begin{array}{l}\text { Decursin } \\
(0-50 \mu \mathrm{g} / \mathrm{mL})\end{array}$ & $\begin{array}{c}\text { Doxorubicin-resistant } \\
\text { human breast carcinoma } \\
(\mathrm{MCF} / \mathrm{ADR})\end{array}$ & $\begin{array}{l}\text { Inhibition of P-glycoprotein } \\
\text { expression }\end{array}$ & [73] \\
\hline
\end{tabular}

\section{A Rapid Review of the Clinical Trials of SH003}

Current clinical trials of SH003 in development are listed in Table 3. This first-inhuman phase 1 study of $\mathrm{SH} 003$ was conducted with patients with solid cancers; the study may be the first phase 1 clinical trial of a herbal mixture conducted in Korea. The patients were recruited and administered one to four tablets of SH003 for three weeks at the designated dose level. Patients in cohorts 1,2, and 3 took 1200, 2400, or $4800 \mathrm{mg} /$ day in this respect. The aim of this clinical trial was to examine the maximum tolerated dose (MTD) of SH003 alone. The MTD is defined as the maximum dose that does not cause adverse events of grade 3 or more according to the Common Terminology Criteria for Adverse Events (CTCAE) version 4.03 from the National Cancer Institute in more than two of six participants. Since no adverse events of grade 3 or more were observed, $4800 \mathrm{mg} /$ day was the highest dose determined to be the MTD of SH003. Considering the efficacy of SH003, a phase 2 clinical trial with patients with cancer at a dose of $4800 \mathrm{mg} /$ day ought to be planned.

Table 3. Current clinical trials of SH003 in development.

\begin{tabular}{|c|c|c|c|c|c|c|}
\hline Clinical Trial & Phase & Study Description & Intervention & Targets & $\begin{array}{l}\text { Sponsors and } \\
\text { Collaborators }\end{array}$ & Refs. \\
\hline $\begin{array}{c}\text { NCT03081819 } \\
\text { (ClinicalTrials.gov) }\end{array}$ & Phase I & $\begin{array}{l}\text { SH003 for evaluating } \\
\text { safe dose range in } \\
\text { patients with solid cancer }\end{array}$ & SH003 & $\begin{array}{l}\text { Solid tumor, } \\
\text { adult }\end{array}$ & $\begin{array}{c}\text { Kyung Hee } \\
\text { University } \\
\text { Medical Center }\end{array}$ & [17] \\
\hline $\begin{array}{c}\text { NCT04360317 } \\
\text { (ClinicalTrials.gov) }\end{array}$ & Phase I & $\begin{array}{c}\text { Safety of the } \\
\text { combination of SH003 } \\
\text { and docetaxel in patients } \\
\text { with solid cancer }\end{array}$ & $\begin{array}{l}\text { Combination } \\
\text { of SH003 and } \\
\text { docetaxel }\end{array}$ & Solid tumor & $\begin{array}{c}\text { Kyung Hee } \\
\text { University } \\
\text { Medical Center }\end{array}$ & [18] \\
\hline
\end{tabular}


As previously mentioned, combination therapy with conventional therapies has earned great interest in treating cancer patients. As SH003 has been investigated for a feasible combination with conventional drugs, a clinical trial has been ongoing, confirming the safety of SH0O3 and docetaxel in patients with solid cancer.

\title{
6. Conclusions and Future Perspectives
}

Although natural compounds and extracts of herbal medicines are promising chemopreventive agents, there is still a lack of evidence. However, SH003 so far has been proved to possess positive effects, showing greater tumorigenicity and cytotoxic effects while inhibiting tumor growth and suppressing the proliferation of cells in various targeted lung, breast, prostate, cervical, and gastric cancer cells. The next step for SH003 is to perform enough RCTs to analyze patients' performance status, tolerance of side effects, level of drugrelated toxicity, tumor response, and length of survival to improve the efficacy and safety. Furthermore, combination therapies with conventional chemotherapy or radiotherapy will become exceptionally valuable in the future, such that more research efforts with SH003 in the field of integrative cancer therapies are much needed. Well-designed RCTs will provide the most accurate estimates of treatment effects while helping physicians to plan the best treatment course for patients. Overall, the potential of $\mathrm{SH} 003$ as a chemotherapeutic agent has been well-presented so far; however, continuous further work is warranted to facilitate better cancer patient care in the near future.

\begin{abstract}
Author Contributions: Conceptualization, B.-Y.Y. and K.L.; methodology, B.-Y.Y. and K.L.; formal analysis, S.M., Y.-J.C. and K.L.; investigation, C.C.; resources, S.M., Y.-J.C. and K.L.; writing-original draft preparation, B.-Y.Y. and K.L.; writing-review and editing, B.-Y.Y., J.I., K.C. and K.L.; visualization, Y.-J.C.; supervision, S.-G.K.; project administration, B.-Y.Y., K.L., C.C. and S.-G.K. All authors have read and agreed to the published version of the manuscript.
\end{abstract}

Funding: This work was supported by the National Research Foundation of Korea (NRF) grant funded by the Korean government (MIST) (no. 2020R1A5A2019413).

Conflicts of Interest: The authors declare no conflict of interest.

\section{References}

1. World Health Organization Home Page. Available online: https:/ /www.who.int/news-room/fact-sheets/detail/cancer (accessed on 28 January 2022).

2. Qi, F.; Li, A.; Inagaki, Y.; Gao, J.; Li, J.; Kokudo, N.; Li, X.K.; Tang, W. Chinese herbal medicines as adjuvant treatment during chemo- or radio-therapy for cancer. Biosci. Trends 2010, 4, 297-307. [PubMed]

3. Cancers Home Page. Available online: https://www.cancer.gov/about-cancer/treatment/types (accessed on 28 January 2022).

4. Aung, T.N.; Qu, Z.; Kortschak, R.D.; Adelson, D.L. Understanding the Effectiveness of Natural Compound Mixtures in Cancer through Their Molecular Mode of Action. Int. J. Mol. Sci. 2017, 18, 656. [CrossRef] [PubMed]

5. Rejhova, A.; Opattova, A.; Cumova, A.; Sliva, D.; Vodicka, P. Natural compounds and combination therapy in colorectal cancer treatment. Eur. J. Med. Chem. 2018, 144, 582-594. [CrossRef] [PubMed]

6. Zhang, X.W.; Liu, W.; Jiang, H.L.; Mao, B. Chinese Herbal Medicine for Advanced Non-Small-Cell Lung Cancer: A Systematic Review and Meta-Analysis. Am. J. Chin. Med. 2018, 46, 923-952. [CrossRef]

7. Ferrucci, V.; Boffa, I.; De Masi, G.; Zollo, M. Natural compounds for pediatric cancer treatment. Naunyn-Schmiedeberg's Arch. Pharmacol. 2016, 389, 131-149. [CrossRef]

8. Cheng, A.L.; Hsu, C.H.; Lin, J.K.; Hsu, M.M.; Ho, Y.F.; Shen, T.S.; Ko, J.Y.; Lin, J.T.; Lin, B.R.; Ming-Shiang, W.; et al. Phase I clinical trial of curcumin, a chemopreventive agent, in patients with high-risk or pre-malignant lesions. Anticancer. Res. 2001, 21, 2895-2900.

9. Wang, S.; Long, S.; Wu, W. Application of Traditional Chinese Medicines as Personalized Therapy in Human Cancers. Am. J. Chin. Med. 2018, 46, 953-970. [CrossRef]

10. Huang, M.Y.; Zhang, L.L.; Ding, J.; Lu, J.J. Anticancer drug discovery from Chinese medicinal herbs. Chin. Med. 2018, 13, 35. [CrossRef]

11. Yin, S.Y.; Wei, W.C.; Jian, F.Y.; Yang, N.S. Therapeutic applications of herbal medicines for cancer patients. Evid.-Based Complement. Altern. Med. eCAM 2013, 2013, 302426. [CrossRef]

12. National College of Korean Medicine Publication Committee on Joint Textbook. Herbology; Younglimsa: Seoul, Korea, 2016. 
13. Kim, M.C.; Lee, G.H.; Kim, S.J.; Chung, W.S.; Kim, S.S.; Ko, S.G.; Um, J.Y. Immune-enhancing effect of Danggwibohyeoltang, an extract from Astragali Radix and Angelicae gigantis Radix, in vitro and in vivo. Immunopharmacol. Immunotoxicol. 2012, 34, 66-73. [CrossRef]

14. Kim, S.R.; Seo, H.S.; Choi, H.S.; Cho, S.G.; Kim, Y.K.; Hong, E.H.; Shin, Y.C.; Ko, S.G. Trichosanthes kirilowii Ethanol Extract and Cucurbitacin D Inhibit Cell Growth and Induce Apoptosis through Inhibition of STAT3 Activity in Breast Cancer Cells Evid.-Based Complement. Altern. Med. eCAM 2013, 2013, 975350. [CrossRef] [PubMed]

15. Choi, Y.K.; Cho, S.G.; Woo, S.M.; Yun, Y.J.; Park, S.; Shin, Y.C.; Ko, S.G. Herbal extract SH003 suppresses tumor growth and metastasis of MDA-MB-231 breast cancer cells by inhibiting STAT3-IL-6 signaling. Mediat. Inflamm. 2014, 2014, 492173. [CrossRef] [PubMed]

16. Choi, Y.K.; Cho, S.G.; Choi, Y.J.; Yun, Y.J.; Lee, K.M.; Lee, K.; Yoo, H.H.; Shin, Y.C.; Ko, S.G. SH003 suppresses breast cancer growth by accumulating p62 in autolysosomes. Oncotarget 2017, 8, 88386-88400. [CrossRef] [PubMed]

17. Cheon, C.; Ko, S.G. A Phase I Study to Evaluate the Safety of the Herbal Medicine SH003 in Patients With Solid Cancer. Integr. Cancer Ther. 2020, 19, 1534735420911442. [CrossRef]

18. Cheon, C.; Ko, S.G. Phase I study to evaluate the maximum tolerated dose of the combination of SH003 and docetaxel in patients with solid cancer: A study protocol. Medicine 2020, 99, e22228. [CrossRef]

19. Siegel, R.L.; Miller, K.D.; Fuchs, H.E.; Jemal, A. Cancer Statistics, 2021. CA Cancer J. Clin. 2021, 71, 7-33. [CrossRef]

20. Holliday, D.L.; Speirs, V. Choosing the right cell line for breast cancer research. Breast Cancer Res. BCR 2011, 13, 215. [CrossRef]

21. Neve, R.M.; Chin, K.; Fridlyand, J.; Yeh, J.; Baehner, F.L.; Fevr, T.; Clark, L.; Bayani, N.; Coppe, J.P.; Tong, F.; et al. A collection of breast cancer cell lines for the study of functionally distinct cancer subtypes. Cancer Cell 2006, 10, 515-527. [CrossRef]

22. Waks, A.G.; Winer, E.P. Breast Cancer Treatment: A Review. JAMA 2019, 321, 288-300. [CrossRef]

23. Yin, L.; Duan, J.J.; Bian, X.W.; Yu, S.C. Triple-negative breast cancer molecular subtyping and treatment progress. Breast Cancer Res. BCR 2020, 22, 61. [CrossRef]

24. Choi, E.K.; Kim, S.M.; Hong, S.W.; Moon, J.H.; Shin, J.S.; Kim, J.H.; Hwang, I.Y.; Jung, S.A.; Lee, D.H.; Lee, E.Y.; et al. SH003 selectively induces p73dependent apoptosis in triplenegative breast cancer cells. Mol. Med. Rep. 2016, 14, 3955-3960. [CrossRef] [PubMed]

25. Housman, G.; Byler, S.; Heerboth, S.; Lapinska, K.; Longacre, M.; Snyder, N.; Sarkar, S. Drug resistance in cancer: An overview. Cancers 2014, 6, 1769-1792. [CrossRef] [PubMed]

26. Mansoori, B.; Mohammadi, A.; Davudian, S.; Shirjang, S.; Baradaran, B. The Different Mechanisms of Cancer Drug Resistance: A Brief Review. Adv. Pharm. Bull. 2017, 7, 339-348. [CrossRef] [PubMed]

27. Wang, X.; Zhang, H.; Chen, X. Drug resistance and combating drug resistance in cancer. Cancer Drug Resist. 2019, 2, 141-160. [CrossRef] [PubMed]

28. Yuan, R.; Hou, Y.; Sun, W.; Yu, J.; Liu, X.; Niu, Y.; Lu, J.J.; Chen, X. Natural products to prevent drug resistance in cancer chemotherapy: A review. Ann. N. Y. Acad. Sci. 2017, 1401, 19-27. [CrossRef] [PubMed]

29. Wu, J.; Liu, Y.; Fang, C.; Zhao, L.; Lin, L.; Lu, L. Traditional Chinese Medicine Preparation Combined Therapy May Improve Chemotherapy Efficacy: A Systematic Review and Meta-Analysis. Evid.-Based Complement. Altern. Med. eCAM 2019, 2019, 5015824. [CrossRef]

30. Woo, S.M.; Kim, A.J.; Choi, Y.K.; Shin, Y.C.; Cho, S.G.; Ko, S.G. Synergistic Effect of SH003 and Doxorubicin in Triple-negative Breast Cancer. Phytother. Res. PTR 2016, 30, 1817-1823. [CrossRef]

31. Choi, H.S.; Cho, S.G.; Kim, M.K.; Lee, H.J.; Moon, S.H.; Jang, H.J.; Ko, S.G. SH003 enhances paclitaxel chemosensitivity in MCF-7/PAX breast cancer cells through inhibition of MDR1 activity. Mol. Cell. Biochem. 2017, 426, 1-8. [CrossRef]

32. Seo, H.S.; Ku, J.M.; Lee, H.J.; Woo, J.K.; Cheon, C.; Kim, M.; Jang, B.H.; Shin, Y.C.; Ko, S.G. SH003 reverses drug resistance by blocking signal transducer and activator of transcription 3 (STAT3) signaling in breast cancer cells. Biosci. Rep. 2017, 37, BSR20170125. [CrossRef]

33. Landis, S.H.; Murray, T.; Bolden, S.; Wingo, P.A. Cancer statistics, 1998. CA Cancer J. Clin. 1998, 48, 6-29. [CrossRef]

34. Kriegsmann, M.; Haag, C.; Weis, C.A.; Steinbuss, G.; Warth, A.; Zgorzelski, C.; Muley, T.; Winter, H.; Eichhorn, M.E.; Eichhorn, F.; et al. Deep Learning for the Classification of Small-Cell and Non-Small-Cell Lung Cancer. Cancers 2020, 12, 1604. [CrossRef] [PubMed]

35. Zheng, M. Classification and Pathology of Lung Cancer. Surg. Oncol. Clin. N. Am. 2016, 25, 447-468. [CrossRef] [PubMed]

36. Chu, Q.; Vincent, M.; Logan, D.; Mackay, J.A.; Evans, W.K.; Lung Cancer Disease Site Group of Cancer Care Ontario's Program in Evidence-base Care. Taxanes as first-line therapy for advanced non-small cell lung cancer: A systematic review and practice guideline. Lung Cancer 2005, 50, 355-374. [CrossRef]

37. Hildebrandt, M.A.; Gu, J.; Wu, X. Pharmacogenomics of platinum-based chemotherapy in NSCLC. Expert Opin. Drug Metab. Toxicol. 2009, 5, 745-755. [CrossRef] [PubMed]

38. Herbst, R.S.; Khuri, F.R. Mode of action of docetaxel-A basis for combination with novel anticancer agents. Cancer Treat. Rev. 2003, 29, 407-415. [CrossRef]

39. Xiao, H.; Verdier-Pinard, P.; Fernandez-Fuentes, N.; Burd, B.; Angeletti, R.; Fiser, A.; Horwitz, S.B.; Orr, G.A. Insights into the mechanism of microtubule stabilization by Taxol. Proc. Natl. Acad. Sci. USA 2006, 103, 10166-10173. [CrossRef] [PubMed]

40. He, X.; Wang, J.; Li, Y. Efficacy and safety of docetaxel for advanced non-small-cell lung cancer: A meta-analysis of Phase III randomized controlled trials. OncoTargets Ther. 2015, 8, 2023-2031. [CrossRef] 
41. d'Amato, T.A.; Landreneau, R.J.; McKenna, R.J.; Santos, R.S.; Parker, R.J. Prevalence of in vitro extreme chemotherapy resistance in resected nonsmall-cell lung cancer. Ann. Thorac. Surg. 2006, 81, 440-446, discussion in 446-447. [CrossRef]

42. Baker, J.; Ajani, J.; Scotte, F.; Winther, D.; Martin, M.; Aapro, M.S.; von Minckwitz, G. Docetaxel-related side effects and their management. Eur. J. Oncol. Nurs. 2009, 13, 49-59. [CrossRef]

43. Cassileth, B.R.; Rizvi, N.; Deng, G.; Yeung, K.S.; Vickers, A.; Guillen, S.; Woo, D.; Coleton, M.; Kris, M.G. Safety and pharmacokinetic trial of docetaxel plus an Astragalus-based herbal formula for non-small cell lung cancer patients. Cancer Chemother. Pharmacol. 2009, 65, 67-71. [CrossRef]

44. Zhao, L.; Zhao, A.G.; Zhao, G.; Xu, Y.; Zhu, X.H.; Cao, N.D.; Zheng, J.; Yang, J.K.; Xu, J.H. Survival benefit of traditional chinese herbal medicine (a herbal formula for invigorating spleen) in gastric cancer patients with peritoneal metastasis. Evid.-Based Complement. Altern. Med. eCAM 2014, 2014, 625493. [CrossRef] [PubMed]

45. Lee, Y.C.; Chen, Y.H.; Huang, Y.C.; Lee, Y.F.; Tsai, M.Y. Effectiveness of Combined Treatment with Traditional Chinese Medicine and Western Medicine on the Prognosis of Patients with Breast Cancer. J. Altern. Complement. Med. 2020, 26, 833-840. [CrossRef] [PubMed]

46. Tang, W.R.; Yang, S.H.; Yu, C.T.; Wang, C.C.; Huang, S.T.; Huang, T.H.; Chiang, M.C.; Chang, Y.C. Long-Term Effectiveness of Combined Treatment with Traditional Chinese Medicine and Western Medicine on the Prognosis of Patients with Lung Cancer. J. Altern. Complement. Med. 2016, 22, 212-222. [CrossRef] [PubMed]

47. Jeong, M.S.; Lee, K.W.; Choi, Y.J.; Kim, Y.G.; Hwang, H.H.; Lee, S.Y.; Jung, S.E.; Park, S.A.; Lee, J.H.; Joo, Y.J.; et al. Synergistic Antitumor Activity of SH003 and Docetaxel via EGFR Signaling Inhibition in Non-Small Cell Lung Cancer. Int. J. Mol. Sci. 2021, 22, 8405. [CrossRef]

48. Choi, Y.J.; Choi, Y.K.; Lee, K.M.; Cho, S.G.; Kang, S.Y.; Ko, S.G. SH003 induces apoptosis of DU145 prostate cancer cells by inhibiting ERK-involved pathway. BMC Complement. Altern. Med. 2016, 16, 507. [CrossRef]

49. Lee, K.M.; Lee, K.; Choi, Y.K.; Choi, Y.J.; Seo, H.S.; Ko, S.G. SH003induced G1 phase cell cycle arrest induces apoptosis in HeLa cervical cancer cells. Mol. Med. Rep. 2017, 16, 8237-8244. [CrossRef]

50. Kim, T.W.; Cheon, C.; Ko, S.G. SH003 activates autophagic cell death by activating ATF4 and inhibiting G9a under hypoxia in gastric cancer cells. Cell Death Dis. 2020, 11, 717. [CrossRef]

51. De Palma, M.; Biziato, D.; Petrova, T.V. Microenvironmental regulation of tumour angiogenesis. Nat. Rev. Cancer 2017, 17, 457-474. [CrossRef]

52. Teleanu, R.I.; Chircov, C.; Grumezescu, A.M.; Teleanu, D.M. Tumor Angiogenesis and Anti-Angiogenic Strategies for Cancer Treatment. J. Clin. Med. 2019, 9, 84. [CrossRef]

53. Choi, H.S.; Kim, M.K.; Lee, K.; Lee, K.M.; Choi, Y.K.; Shin, Y.C.; Cho, S.G.; Ko, S.G. SH003 represses tumor angiogenesis by blocking VEGF binding to VEGFR2. Oncotarget 2016, 7, 32969-32979. [CrossRef]

54. Zhang, S. Chemotherapy-induced peripheral neuropathy and rehabilitation: A review. Semin. Oncol. 2021, 48, 193-207. [CrossRef]

55. Chan, Y.N.; Jheng, Y.W.; Wang, P.J.; Chen, C.Y.; Lin, M.W.; Wang, Y.J. Taxane-Induced Peripheral Neuropathy: Objective and Subjective Comparison Between Paclitaxel and Docetaxel in Patients With Breast Cancer. Clin. J. Oncol. Nurs. 2019, 23, 494-501. [CrossRef] [PubMed]

56. Engels, F.K.; Sparreboom, A.; Mathot, R.A.; Verweij, J. Potential for improvement of docetaxel-based chemotherapy: A pharmacological review. Br. J. Cancer 2005, 93, 173-177. [CrossRef] [PubMed]

57. Fu, B.; Wang, N.; Tan, H.Y.; Li, S.; Cheung, F.; Feng, Y. Multi-Component Herbal Products in the Prevention and Treatment of Chemotherapy-Associated Toxicity and Side Effects: A Review on Experimental and Clinical Evidences. Front. Pharmacol. 2018, 9, 1394. [CrossRef] [PubMed]

58. Lee, K.; Ku, J.M.; Choi, Y.J.; Hwang, H.H.; Jeong, M.; Kim, Y.G.; Kim, M.J.; Ko, S.G. Herbal Prescription SH003 Alleviates Docetaxel-Induced Neuropathic Pain in C57BL/6 Mice. Evid.-Based Complement. Altern. Med. eCAM 2021, 2021, 4120334 [CrossRef] [PubMed]

59. Florea, A.M.; Busselberg, D. Cisplatin as an anti-tumor drug: Cellular mechanisms of activity, drug resistance and induced side effects. Cancers 2011, 3, 1351-1371. [CrossRef] [PubMed]

60. Ohm, J.E.; Carbone, D.P. Immune dysfunction in cancer patients. Oncology 2002, 16, 11-18. [PubMed]

61. Wang, S.; Long, S.; Deng, Z.; Wu, W. Positive Role of Chinese Herbal Medicine in Cancer Immune Regulation. Am. J. Chin. Med. 2020, 48, 1577-1592. [CrossRef] [PubMed]

62. Wang, Y.; Zhang, Q.; Chen, Y.; Liang, C.L.; Liu, H.; Qiu, F.; Dai, Z. Antitumor effects of immunity-enhancing traditional Chinese medicine. Biomed. Pharmacother. 2020, 121, 109570. [CrossRef] [PubMed]

63. Han, N.R.; Kim, K.C.; Kim, J.S.; Ko, S.G.; Park, H.J.; Moon, P.D. The immune-enhancing effects of a mixture of Astragalus membranaceus (Fisch.) Bunge, Angelica gigas Nakai, and Trichosanthes Kirilowii (Maxim.) or its active constituent nodakenin. J. Ethnopharmacol. 2022, 285, 114893. [CrossRef]

64. Seo, H.S.; Choi, H.S.; Kim, S.R.; Choi, Y.K.; Woo, S.M.; Shin, I.; Woo, J.K.; Park, S.Y.; Shin, Y.C.; Ko, S.G. Apigenin induces apoptosis via extrinsic pathway, inducing p53 and inhibiting STAT3 and NFkappaB signaling in HER2-overexpressing breast cancer cells. Mol. Cell. Biochem. 2012, 366, 319-334. [CrossRef] [PubMed]

65. Seo, H.S.; Ku, J.M.; Choi, H.S.; Woo, J.K.; Jang, B.H.; Shin, Y.C.; Ko, S.G. Induction of caspase-dependent apoptosis by apigenin by inhibiting STAT3 signaling in HER2-overexpressing MDA-MB-453 breast cancer cells. Anticancer. Res. 2014, 34, $2869-2882$. [PubMed] 
66. Seo, H.S.; Jo, J.K.; Ku, J.M.; Choi, H.S.; Choi, Y.K.; Woo, J.K.; Kim, H.I.; Kang, S.Y.; Lee, K.M.; Nam, K.W.; et al. Induction of caspase-dependent extrinsic apoptosis by apigenin through inhibition of signal transducer and activator of transcription 3 (STAT3) signalling in HER2-overexpressing BT-474 breast cancer cells. Biosci. Rep. 2015, 35, e00276. [CrossRef] [PubMed]

67. Chen, J.C.; Chiu, M.H.; Nie, R.L.; Cordell, G.A.; Qiu, S.X. Cucurbitacins and cucurbitane glycosides: Structures and biological activities. Nat. Prod. Rep. 2005, 22, 386-399. [CrossRef]

68. Jayaprakasam, B.; Seeram, N.P.; Nair, M.G. Anticancer and antiinflammatory activities of cucurbitacins from Cucurbita andreana. Cancer Lett. 2003, 189, 11-16. [CrossRef]

69. Ku, J.M.; Kim, S.R.; Hong, S.H.; Choi, H.S.; Seo, H.S.; Shin, Y.C.; Ko, S.G. Cucurbitacin D induces cell cycle arrest and apoptosis by inhibiting STAT3 and NF-kappaB signaling in doxorubicin-resistant human breast carcinoma (MCF7/ADR) cells. Mol. Cell. Biochem. 2015, 409, 33-43. [CrossRef]

70. Hong, S.H.; Ku, J.M.; Lim, Y.S.; Lee, S.Y.; Kim, J.H.; Cheon, C.; Ko, S.G. Cucurbitacin D Overcomes Gefitinib Resistance by Blocking EGF Binding to EGFR and Inducing Cell Death in NSCLCs. Front. Oncol. 2020, 10, 62. [CrossRef]

71. Kim, M.S.; Lee, K.; Ku, J.M.; Choi, Y.J.; Mok, K.; Kim, D.; Cheon, C.; Ko, S.G. Cucurbitacin D Induces G2/M Phase Arrest and Apoptosis via the ROS/p38 Pathway in Capan-1 Pancreatic Cancer Cell Line. Evid.-Based Complement. Altern. Med. eCAM 2020, 2020, 6571674. [CrossRef]

72. Imran, M.; Salehi, B.; Sharifi-Rad, J.; Aslam Gondal, T.; Saeed, F.; Imran, A.; Shahbaz, M.; Tsouh Fokou, P.V.; Umair Arshad, M.; Khan, H.; et al. Kaempferol: A Key Emphasis to Its Anticancer Potential. Molecules 2019, 24, 2277. [CrossRef]

73. Kim, T.W.; Lee, S.Y.; Kim, M.; Cheon, C.; Ko, S.G. Kaempferol induces autophagic cell death via IRE1-JNK-CHOP pathway and inhibition of G9a in gastric cancer cells. Cell Death Dis. 2018, 9, 875. [CrossRef]

74. Boots, A.W.; Wilms, L.C.; Swennen, E.L.; Kleinjans, J.C.; Bast, A.; Haenen, G.R. In vitro and ex vivo anti-inflammatory activity of quercetin in healthy volunteers. Nutrition 2008, 24, 703-710. [CrossRef] [PubMed]

75. Coskun, O.; Kanter, M.; Korkmaz, A.; Oter, S. Quercetin, a flavonoid antioxidant, prevents and protects streptozotocin-induced oxidative stress and beta-cell damage in rat pancreas. Pharmacol. Res. 2005, 51, 117-123. [CrossRef]

76. Igura, K.; Ohta, T.; Kuroda, Y.; Kaji, K. Resveratrol and quercetin inhibit angiogenesis in vitro. Cancer Lett. 2001, 171, 11-16. [CrossRef]

77. Reyes-Farias, M.; Carrasco-Pozo, C. The Anti-Cancer Effect of Quercetin: Molecular Implications in Cancer Metabolism. Int. J. Mol. Sci. 2019, 20, 3177. [CrossRef]

78. Rauf, A.; Imran, M.; Khan, I.A.; Ur-Rehman, M.; Gilani, S.A.; Mehmood, Z.; Mubarak, M.S. Anticancer potential of quercetin: A comprehensive review. Phytother. Res. PTR 2018, 32, 2109-2130. [CrossRef] [PubMed]

79. Seo, H.S.; Ku, J.M.; Choi, H.S.; Choi, Y.K.; Woo, J.K.; Kim, M.; Kim, I.; Na, C.H.; Hur, H.; Jang, B.H.; et al. Quercetin induces caspase-dependent extrinsic apoptosis through inhibition of signal transducer and activator of transcription 3 signaling in HER2-overexpressing BT-474 breast cancer cells. Oncol. Rep. 2016, 36, 31-42. [CrossRef] [PubMed] 